\title{
The Integration of Loyalty, Satisfaction, and Relationship Commitment Models to Predict Customer Retention in Pakistani Telecom Sector
}

\author{
Reema Frooghi ${ }^{1}$, Sahar Afshan ${ }^{2}$ and Syeda NazneenWaseem ${ }^{3 *}$
}

\begin{abstract}
Based on SERVQUAL Model, customer loyalty framework, and relationship commitment model, this meta-analysis examines the effect of these well-defined models on customer retention. The study validates the impact of the given welldeveloped models and helps to develop strategies for enhancing and developing customer retention. The study utilized exploratory factor analysis, confirmatory factor analysis, and structural equation modeling to analyze customer retention outcome model. It was found that all three chosen models were found to have a significant impact on customer retention in telecom sector of Pakistan. The study helps in devising strategies for increasing and improving service satisfaction, customer loyalty and customer trust towards an increase in customer retention. The contribution of this study is the construction of the structural path and measurement models of customer retention practices and provides operational competitive outcomes that could facilitate future research on customer retention in service industry.
\end{abstract}

Keywords: Service Satisfaction, Customer Loyalty, Pakistan Telecom Sector, Trust, Customer Retention.

\section{Introduction}

Telecom sector plays a pivotal role in the economy in terms of providing employment, contribution to national exchequer through taxes and attracting foreign investment in the country (Ali et al., 2010). Due to these reasons significance of telecom sector is stimulated by many management scholars to dedicate more teaching and research attention to this sector (Szyperski \& Loebbecke, 1999). Modern business uses every possible measure to enhance its customer segment. The use of internet in providing value added services in communication

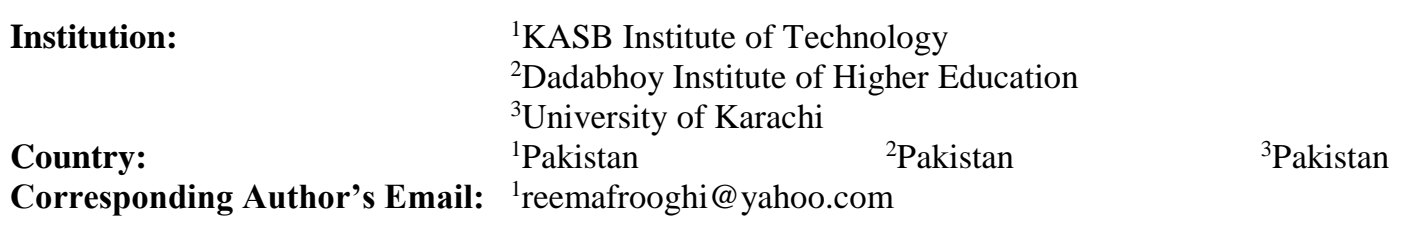

*The material presented by the author does not necessarily portray the view point of the editors/ editorial board and the management of ORIC, Iqra University, Main Campus, Karachi-PAKISTAN. 
businesses especially in consumer markets is growing rapidly. Competition in the online world is increasing because of involvement of a large number of players. In this regard, many companies utilize the technology for establishing a wide variety of businesses online. Appearance on the internet and easy search options are becoming vital for the consumer, therefore it becomes difficult in the development of client base for an online business.

Organizations are integrating service quality measures within their business strategies for improving quality and earning a good profit (Gawyar et al., 2014). Effective quality improvement programs not only lead to increase market penetration and better productivity but also provide an edge over the competitors (Pasebani et al., 2012). Hence, business needs now to increase their focus on development loyal customers a positive word of mouth so as to increase their customer base (Casaló et al., 2008). Customer loyalty pushes towards repurchase intentions (Flavian et al., 2008); whereas word of mouth helps in exerts a positive impact on customer choice which is a motivating factor towards increment in market share (Chung and Darke, 2006).

Customer satisfaction is regarded as consumer's emotional reaction which is created after purchase and experience of a product or a service, this accumulation of reaction results in higher customer loyalty and repurchase with the company (Chen, 2011). As customer satisfaction is an important element for the company, therefore higher satisfaction rate results in higher profit and long term relationship with the product/service. Thus this research helps to develop a framework for increasing customer loyalty and devising such strategies.

Pakistan's telecom sector has emerged as the fastest growing sector across Asia in the recent years. Realizing the benefits achieved from the telecom deregulation around the world, Pakistan has moved from the monopolized structure to the deregulated one (Ali et al., 2010). Pakistan's telecom sector has prospered rapidly which has made a big contribution to the country's economy (Arslan et al., 2015). 98 million citizens of the country have been found to be mobile users in the country, which makes telecom sector to generate a profit of 327.8 billion rupees and contribute to the economy (Arslan et al., 2015). Hence, the telecom industry is incessantly coming up with a different call, messaging, internet and other packages to generate better revenues for their respective companies. Teledensity has been improved and facilities have reached $75.2 \%$ of the population also the Telecom revenues during Jul-Dec 2014-2015 amounted to Rs.299.0 billion (Pakistan Economic survey, 2014-2015) thus making it a very lucrative sector for revenue generation and further investment.

As per SBP report (2016); in spite of telecom sectors' significant contribution to GDP it has observed a decline in its growth rate in last few years, the reason is high market expenses due to extensive competition in the industry, thus it is imperative for marketing practitioners and academicians to understand the importance of and to study the underlying factors that affect customer retention empirically. Retaining customers in telecom industry means customers remaining loyal and sticking to the same network and cellular companies without switching it. The critical query in current study aims to identify the aspects that drive customer retention which is regarded as a highly competitive service industry characterized by low switching costs in a competitive market like Pakistan. In doing so, the present research is being carried out to analyze the factors that influence customer retention and their decision to stay with their current telecom service provider. It further aims to examine whether significant relationships exist between service satisfaction, loyalty, and trust with customer retention in Pakistan's telecom sector.

The analysis of some recent research proposes to center their attention on coupling various theoretical models in studying prediction of certain variable suggesting that a broad view in the context is needed (Oliveira, Faria, Thomas \& Popovic, 2014; Afshan \& Sharif, 2016). Therefore complying with this fondness, the present study seeks to analyze customer retention utilizing an inclusive framework by integrating three renowned models of 
satisfaction, loyalty and relationship commitment. The integration of SERVQUAL model with customer loyalty framework and relationship commitment model can provide a profound understanding of customer retention and are wise to combine since they provide improved and better understanding of the said phenomenon.

\section{Literature Review}

\section{Theoretical Background}

The present study comprehended three frameworks to investigate their impact on customer retention. Many past studies strive to explain customer retention but none of the models can explain the phenomenon with the integrative approach (Ali, Ali, Rehman, Yilmaz, Safwan, \& Afzal, 2010; Boohene, Agyapong \& Gonu, 2013). Customer retention which is the ultimate goal of any marketer need to be studied extensively in order to enhance the company's productivity and image; for that purpose this study has integrated the service quality (SERVEQUEL model), the customer relationship management (relationship commitment model) and loyalty factors (customer loyalty model) combine along with the most relevant theories to predict the ultimate target of any service oriented company that is retaining its customers. The present study fills this gap by first time integrating three approaches to explain customer retention in one of the fastest growing service industry that is telecommunication industry, especially within Pakistani context. Mention below is the brief explanation of studied frameworks.

\section{Customer Loyalty Model}

Lin and Wang (2006) has regarded customer loyalty as an important element in e-commerce industry; it plays an important role in the retention of loyal customers and developing longterm customer relationship. Retention of customers is a financial domineering for any industry as attracting new customers is much costly that retaining the older ones. The model proposes customer loyalty as a product of customer satisfaction, perceived value, trust, and habit. These variables help in defining the repurchase behavior. Fig 1, Shows the loyalty framework used in the study.

Figure 1: Customer Loyalty Model

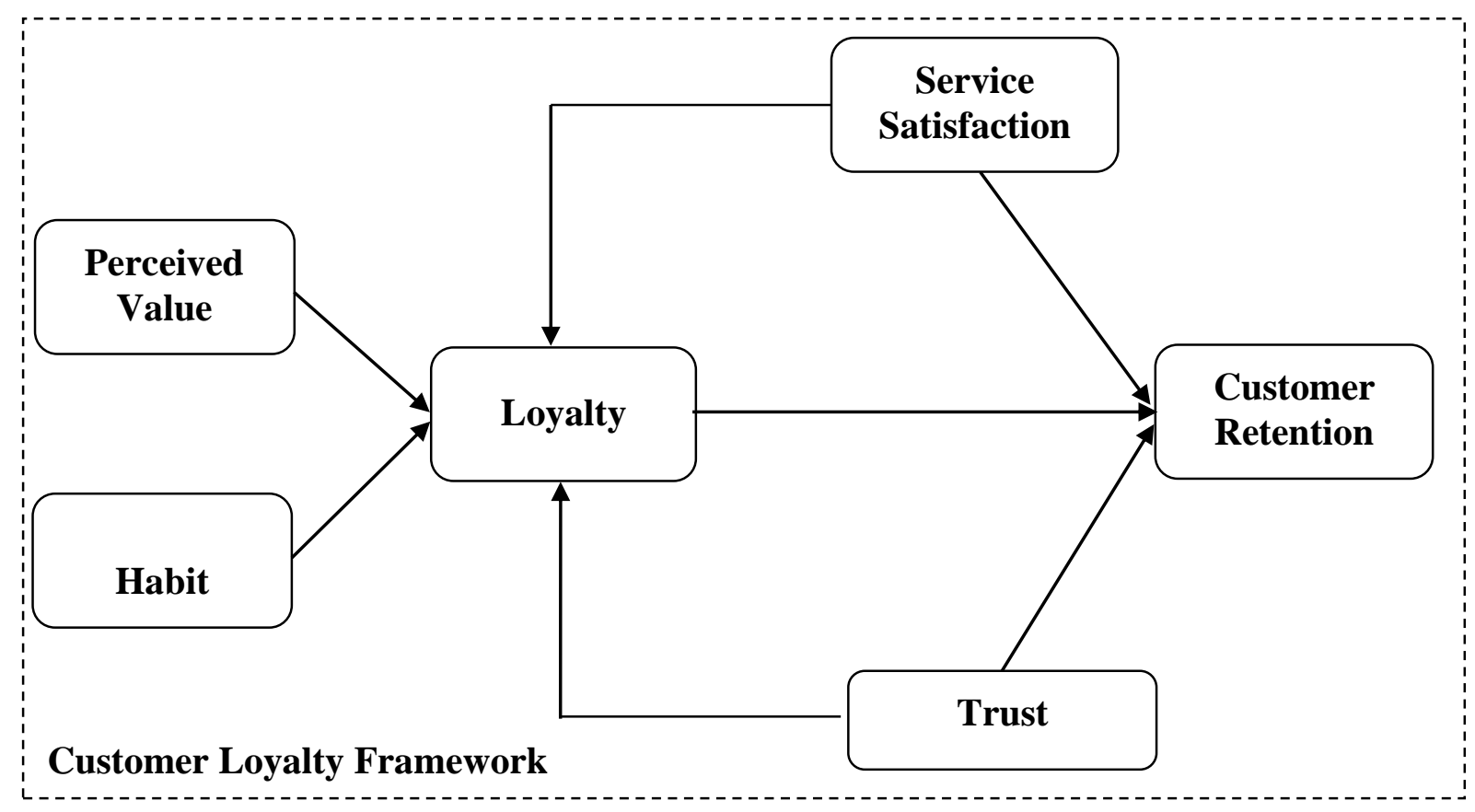


Sharma and Patterson (2000) developed a model depicting the variables of relationship commitment. The model which comprises of technical quality, functional quality and communication effectiveness; which affects trust and in turn relationship commitment. The greater level of trust will result in stronger and greater level of relationship commitment. Sharma and Patterson (2000) defines trust as a reliance on the relation of the buyer and seller that the long-term interest of the buyer will be responded and served.

\section{Figure 2: Relationship Commitment Model}

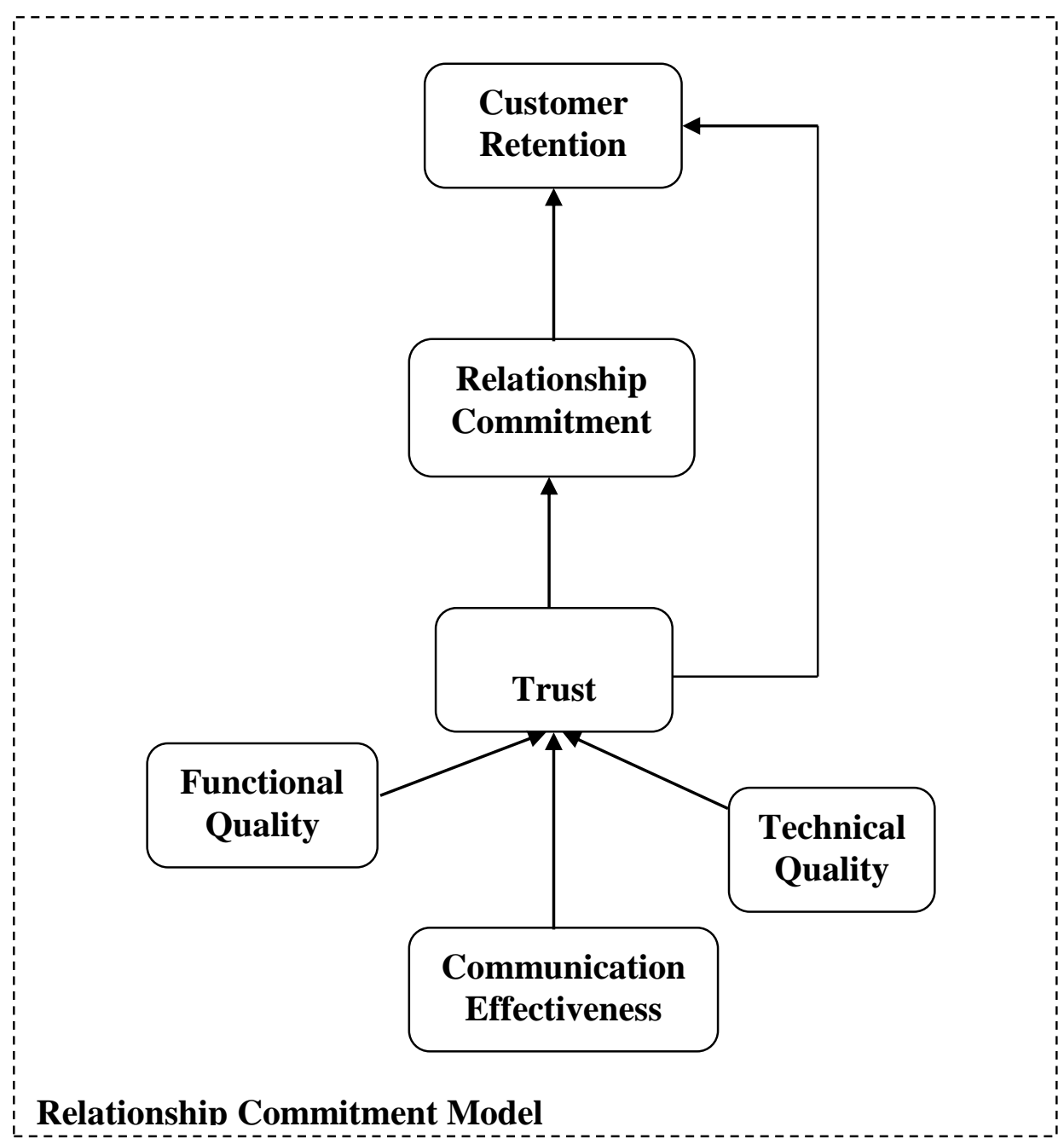

\section{SERVQUAL Model}

Parasuraman, Zeithaml, and Berry (1988) have defined five dimensions of service experience which has been identified as SERVQUAL measures on the basis of five dimensions: responsiveness, reliability, assurance, empathy and tangibility. High-quality service delivery to the customers develops an opportunity for businesses to distinguish themselves in a competitive market (Yavas \& Benkenstein, 2007). Positive word of mouth is a result of better service quality, reduction in complaints and continuousness of company-customer relationship (Caruana, 2002). SERVQUAL delivers technology for measurement and management of service quality (Buttle, 1996). 
Figure 3: SERVQUAL Model

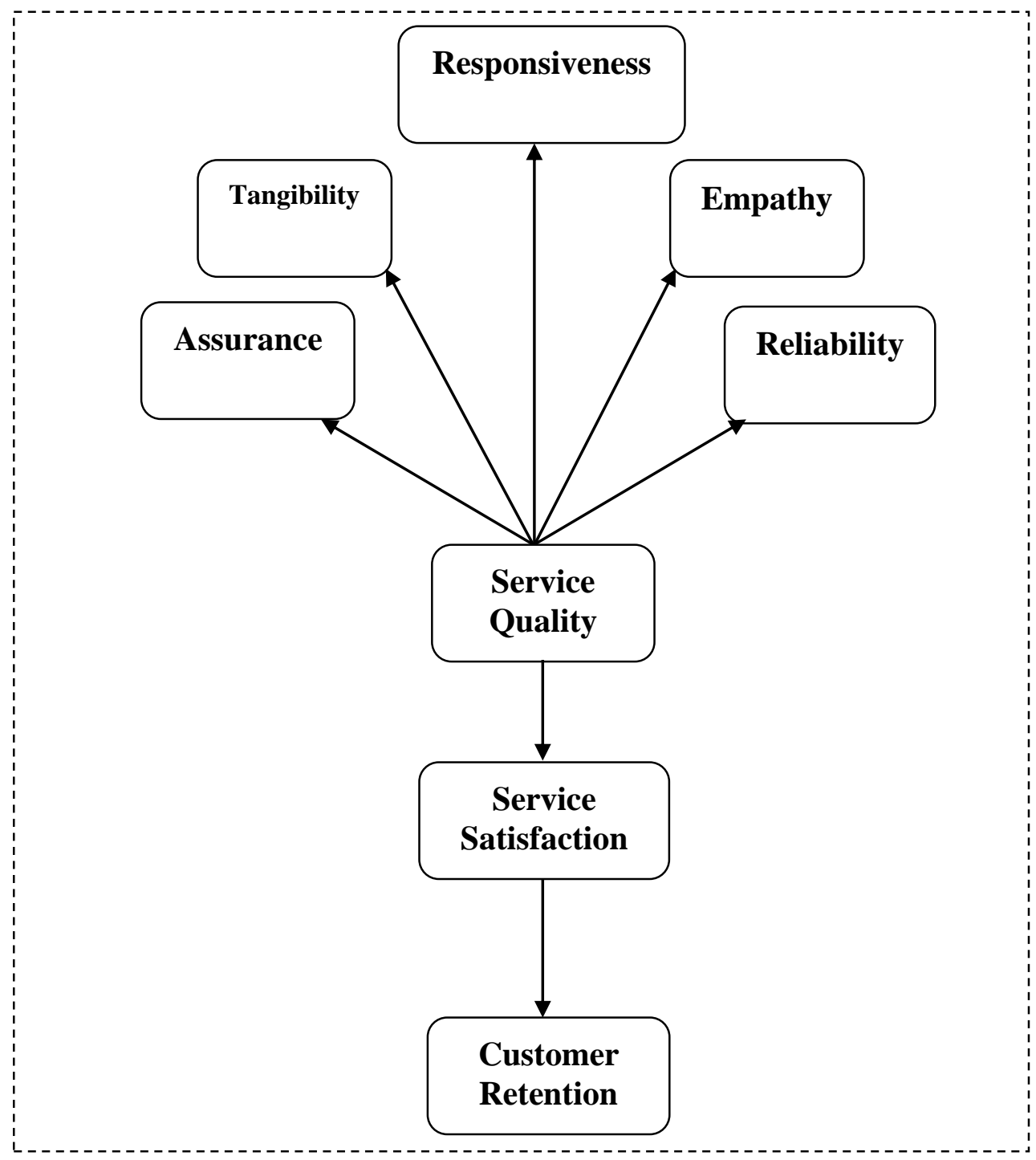

\section{Empirical Studies}

\section{Service Quality}

Service Quality is termed as a long-term cognitive judgment based on the organizational experience of superiority (Yoon, 2010; Parasuraman, Berry \& Zeithaml 1991). There exist two mainstream of research towards service quality: the Nordin School which incorporates the process and outcome dimension (Casalo et al., 2007) and the SERVQUAL which is drawn by the American School (Parasuraman et al., 1985; Parasuraman et al., 1991). For service firms, it is incumbent to have a customer-oriented quality strategy as it is a driving force towards customers' behavioral intentions towards repeat purchase and customer devotion (Zeithaml, 2000; Van-Riel et al., 2001).

According to Pakdil and Kurtulmuşoğlu and Yolu (2014), the service quality dimensions include:

- $\quad$ Reliability - performing promised services based on accuracy and dependability.

- $\quad$ Tangibility - physical facilities, machinery and equipment and appearance of employees. 
- Assurance-courtesy and knowledge of the employees during task performance and the ability for confidence and trust inspiration.

- $\quad$ Responsiveness - willingness and provision of a prompt response to the customers.

- $\quad$ Empathy - care and individualized attention provided to the customer.

- $\quad$ The study conducted by Haghighi et al., (2012) depicts a positive and significant relationship between services qualities perceived by the customers on service satisfaction, based on which we hypothesized the following:

\section{Hypothesis 1: Service quality significantly influences service satisfaction.}

\section{Customer Satisfaction}

Customer satisfaction has been defined as the overall performance of the product/service that the customer enjoys; the overall satisfaction of the customer created loyalty and long term customer relationship with the product/service in use (Fornell et.al 1996). This long term relationship results in greater retention. Customers overall satisfaction is eminent to quality satisfaction. The greater the quality the greater will be the satisfaction thus we can say that satisfaction is an overall evaluation of the service quality being provided to the customer (Fornell 1992; Fornell et al. 1996; Gustafsson et al., 2005). As competition and saturation are being increased in the market it is now becoming incumbent upon companies to increase their attention towards the customers, it is now becoming an important business governance issue (Cardozo, 1965; Chen 2011). Lau \& Lee (1999) argues that customer complaints have a direct impact on customer satisfaction, and which decrease in customer complaints customer satisfaction increases. Haemoon (2000) developed a study to analyze the relationship between customer repurchase intention which is based on customer retention and customer satisfaction and their perceived value, the study found a positive relationship between the given variables. Gustafsson et al., (2005) also supported the relationship of customer satisfaction on customer repurchase intention, therefore we hypothesized the following:

\section{Hypothesis 2: Service satisfaction significantly influences Customer retention. Hypothesis 3: Service satisfaction significantly influences Customer loyalty.}

\section{Customer Loyalty}

Loyalty development helps towards higher future purchase intentions (Andreassen, 1999); loyalty has also been defined as the consumer's intention of repurchase from the same organization again (Edvardsson et al., 2000), it is based on the belief that customer's perceived value from one seller is greater than the customer perceived value of other alternatives available (Hallowell, 1996). Loyalty is now been considered as a significant factor of company's success and sustainability with the passage of time (Flavian et al., 2006; Keating et al., 2003). Loyalty is elaborated as a critical cornerstone of customer relationship management that can be interpreted through customer retention (Gustafsson et al., 2005). For the development of better understanding of customer loyalty which is a driving force towards customer retention, it becomes important to understand the factors that affect behavior; attitude, evaluations, and intentions (Oliver, 1999).

Verhoef (2003) explained the relationship of customer relationship strategies on customer loyalty, the author investigated a positive impact on loyalty programs on customer retention, and we, therefore, hypothesized the following:

\section{Hypothesis 4: Customer loyalty significantly influences customer retention.}

\section{Perceived Value}

Perceived value has been defined as the comparison of what customer receives against the payment that he/she has made (Bolton and Drew, 1991; Johnson et.al, 2005). Perceived value 
has been conceptualized as the relationship between price inputs and outputs received against competition (Johnson et.al, 2005). Value and equity are important constructs when customers are in information-gathering or problem-solving mode (Olsen and Johnson, 2003).

McDougall and Levesque (2000) studied the relationship between different aspects of service quality, perceived value and customer satisfaction and future intentions and loyalty of the customers. The study found out customer satisfaction and perceived value to be a strong driver of customer loyalty. Kuo et al., (2013) developed a conceptual model of service quality on customer loyalty with a moderating impact of perceived value and customer satisfaction. Perceived value positively moderated the effect of service quality on customer loyalty. We, therefore, hypothesized the following:

\section{Hypothesis 5: Perceived value significantly influence Customer loyalty.}

\section{Habit}

Habit decrees behavioral intentions once people gain experience (Zang et al., 2014). Habitual buying behavior and usage results in repurchase intention (Gefen, Karahanna \& Straub, 2003) as a behavior which once becomes a habit or a well-practiced action becomes reflexive and is started to be carried unconsciously (Orbell \& Verplanken, 2015). According to the theory of attitude and attitude change, behavioral intentions are the product of attitude, affect and social norms (Zang et al., 2014). Lin \& Wang (2006) examined the relationship between habit and customer loyalty and found out habit to be a positive indicator of customer loyalty. We, therefore, hypothesized the following:

\section{Hypothesis 6: Habit significantly influences Customer loyalty.}

\section{Relationship Commitment}

Commitment can be distinguished in two aspects. These include affective and calculative commitment (Hansen et al., 2003; Johnson et al., 2001; Gustafsson et al., 2005). Affective commitment is more emotional in nature and is defined as customer's identification and involvement in a company against the trust and development that has been developed (Morgan $\&$ Hunt, 1994). Calculative commitment, on the other hand, is discussed as continuance commitment in literature which is a result of economic based benefits derived from products. This consequently results in a lack of product choice and switching cost (Anderson \& Weitz, 1992). The present study utilized Sharma and Patterson (2000) model showing the determinants of relationship commitment. The model consists of three factors, namely communication effectiveness, technical quality and functional quality, all affected by trust in the relationship which in turns affect relationship commitment. Empirically, Verhoef (2003) investigated the relationship between relationship commitment and customer retention, the results indicates a positive and significant relationship between the variables, we, therefore, hypothesized the following:

\section{Hypothesis 7: Relationship commitment significantly influences Customer retention.}

\section{Trust}

The trust which has been defined as a critical factor for the creation of an association with stakeholders has a direct relationship with customer devotion towards an organization (Ahmad et al., 2015). A customer tends to develop a positive attitude towards the purchase of brand which he feels trustworthy (Lau \& Lee, 1999). Lack of trust is the outcome of security and privacy concerns. Security which is one of the freedoms from danger, risks or doubts not only involves physical safety and financial security but also confidentiality of one's information. It is an important dimension towards customer decision of adopting a service or not. Sharma and 
Patterson (1999) suggest that quality is divided into two core components i.e. technical quality and functional quality. Technical quality as explained by them is the actual outcomes or the core service as perceived by the customers. However, functional quality is concerned with 'what' is delivered and 'how' the service is delivered. It is related to the interaction between service provider and service receiver. It strongly suggests that trust had a great impact on how quality is delivered, both in terms of functional and technical quality. Haghighi, Dorosti, Rahnama and Hoseinpour (2012) study the relationship between customer trust and loyalty in the restaurant industry. It is found that trust is positive to influence loyalty. Similarly, Boohene, Agyapong, and Gonu (2013) in their research on customer retention in commercial banks of Ghana also find trust to have significant positive effect on customer retention. We, therefore, hypothesized the following:

\section{Hypothesis 8: Trust significantly influences Customer loyalty. Hypothesis 9: Trust significantly influences Relationship commitment. Hypothesis 10: Trust significantly influences Customer retention.}

\section{Technical Quality}

Adoption of new technology is easy for few whereas difficult for others. With the usage of innovations, the organizations can excel in achieving technical quality. Technology adoption has been defined as the willingness to adopt new and enhanced technologies for use in personal and professional settings (Parasuraman, 2000; Chen, 2011). The improved efficiency derived through technical quality enhances customer trust and ensures commitment. Gronroos (1988) investigated the relationship of different service quality dimensions on trust and found a significant relationship between technical quality and trust; this relationship has also been supported by the study conducted by Sharma \& Patterson (1999). We, therefore, hypothesized the following:

\section{Hypothesis 11: Technical quality significantly influences trust.}

\section{Functional Quality}

Functional quality has been determined as how the service is received by the customer and the experience in the consumption process (Karna, 2014), it cannot be however easily determined as objectively as technical dimension but it is more important to be evaluated by the organization. Organizational socialization of service customers helps in the development of knowledge, skills, and attitudes which help to best engage with an organization providing the service (Sweeney et al., 2014), which enables a customer to have a better understanding of the service. This helps in the emergence of positive perception for the service and results in the higher trustworthiness of the organization. Sharma \& Patterson (1999) examined the relationship between functional quality and trust and found a positive relationship between the given variables. We, therefore, hypothesized the following:

\section{Hypothesis 12: Functional quality significantly influences Trust.}

\section{Communication Effectiveness}

Communication Effectiveness is referred to as both formal and informal sharing of timely and meaningful information between employee and the customer in a compassionate manner (Sharma \& Patterson, 1999). Communication has been defined as an elementary ingredient for achieving better service quality (Clark, 1992; Headley \& Choi, 1992). Choon Hua et.al (2005) in their study, conducted emphasized on the relationship between increased customer satisfactions which is a result of effective communication. They emphasized the importance of developing effective customer communication for increasing customer loyalty and retention, 
which was also supported by the study conducted by Adamson et al., (2003) conducted on banking sector of Korea. We, therefore, hypothesized the following:

Hypothesis 13: Communication effectiveness significantly influences Trust. Displayed in figure 4 is the hypothesized model of the study:

\section{Figure 4: Hypothesized Model}

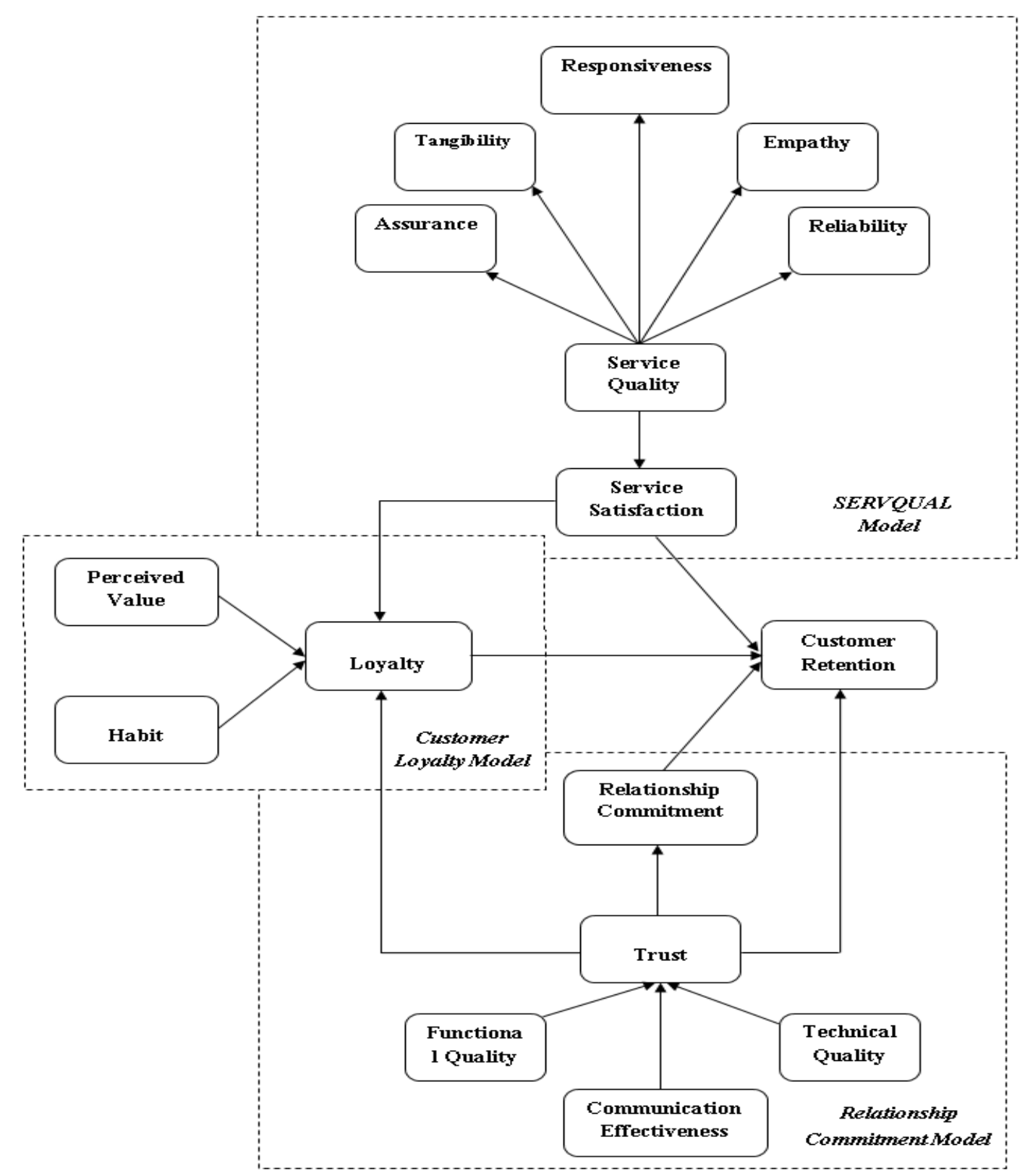

Methodology

\section{Sample and Data Collection}

The present study utilized a sample of 450 responses that was gathered from university students of Karachi. The sample was collected in a period of three months (February 2016 to April 2016) using both offline and online questionnaire written in English. The study utilized convenience sampling method. The method used is consistent with the approach adopted in many previous studies (Luarn \& Lee, 2005). The Questionnaire was sent to 500 respondents out of which 445 responses were collected. The data has been collected through primary source 
i.e. by filling up questionnaires from the respondents via online and offline mediums. For the said purpose different university of Karachi was targeted and the responses were gathered from the respondents.

\section{Data Screening}

In the procedure of data screening, the sample was examined for inspection missing values and resulted in omitting thirty-five responses due to incompleteness. Sixty-eight univariate outliers were also identified and dropped from the dataset. For the detection of multivariate outliers, mahalanobis distance critical chi-square function at $\mathrm{p}<.001$ is used. The results of mahalanobis distance (D2) resulted in twenty-one multivariate outliers. Thus, after removing a total of 124 invalid responses, the final count of the present research was 321.

\section{Measures}

The questionnaire included 15 variables namely: assurance, tangibility, responsiveness, empathy, reliability, service satisfaction, perceived value, habit, loyalty, customer retention, trust, relationship commitment, functional quality, communication effectiveness, technical quality and customer retention.

\section{SERVQUAL Model}

SERVQUAL model consists of service quality and service satisfaction. The measures of service quality were based on 5 items namely: assurance, tangibility, responsiveness, empathy and reliability. The scales have been extracted from Wang, Lo and Yang (2004). The items for Service Satisfaction have been adopted from Wang, Lo and Yang (2004). The item has been measured through five points likert Scale $1=$ Strongly disagree to $5=$ Strongly agree .

\section{Customer Loyalty Model}

Customer loyalty model consists of 3 variables namely: loyalty, perceived value, and habit. Items for loyalty have been adopted from Lin and Wang (2006), items for perceived Value have been adopted from Wang, Lo and Yang (2004) and items for habit have been adopted from Lin and Wang (2006). The item has been measured through five points likert Scale $1=$ Strongly disagree to $5=$ Strongly agree.

\section{Relationship Commitment Model}

Relationship commitment model consists of 5 variables namely: functional quality, communication effectiveness, technical quality, trust and relationship commitment. Items for Functional Quality have been adopted from Sharma \& Patterson (1999), items for Communication Effectiveness have been adopted from Sharma \& Patterson (1999), items for Technical Quality have been adopted from Sharma \& Patterson (1999), items for Trust have been adopted from Alrubaiee and Al-Nazer (2010) and items for relationship commitment have been adopted from Verhoef (2003). The item has been measured through five points likert Scale $1=$ Strongly disagree to $5=$ Strongly agree .

\section{Customer Retention}

Customer Retention has been measured through 4 items which have been adopted from Hennig-Thurau (2004) and Eggert \& Ulaga (2002). The item has been measured through five points Likert Scale $1=$ Strongly disagree to $5=$ Strongly agree .

As suggested by Sekaran (2006), for an instrument to be reliable the cronbach $\alpha$ value should be greater than 0.6 . The reliability of each of the variable was computed, and it was found that 
all the values are above the threshold point as suggested. The cronbach $\alpha$ values have been depicted in Table -1 .

Table 1:

\begin{tabular}{|c|c|c|c|c|c|c|}
\hline \multicolumn{2}{|c|}{ Latent Construct } & \multirow{2}{*}{$\begin{array}{c}\begin{array}{c}\text { No. of } \\
\text { Items }\end{array} \\
4 \\
4 \\
4 \\
4 \\
4 \\
\end{array}$} & \multirow{2}{*}{$\begin{array}{c}\text { Cronbach } \\
\text { Alpha } \\
(\alpha) \\
0.790\end{array}$} & \multirow{2}{*}{$\begin{array}{c}\text { CR } \\
\text { Composite } \\
\text { Reliability } \\
0.689\end{array}$} & \multirow{2}{*}{$\begin{array}{c}\text { AVE } \\
\text { Average } \\
\text { Variance } \\
\text { Extracted }\end{array}$} & \multirow{2}{*}{ 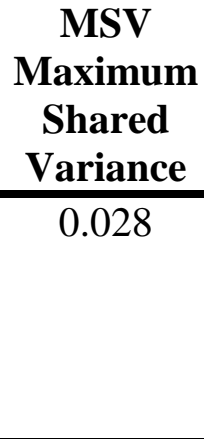 } \\
\hline $\begin{array}{l}\text { Service } \\
\text { Quality }\end{array}$ & $\begin{array}{c}\text { Assurance } \\
\text { Tangibility } \\
\text { Responsiveness } \\
\text { Empathy } \\
\text { Reliability }\end{array}$ & & & & & \\
\hline \multicolumn{2}{|c|}{ Service Satisfaction } & 4 & 0.908 & 0.903 & 0.700 & 0.058 \\
\hline \multicolumn{2}{|l|}{ Loyalty } & 4 & 0.863 & 0.862 & 0.610 & 0.382 \\
\hline \multicolumn{2}{|c|}{ Perceived Value } & 3 & 0.860 & 0.862 & 0.677 & 0.078 \\
\hline \multicolumn{2}{|l|}{ Habit } & 4 & 0.902 & 0.903 & 0.701 & 0.708 \\
\hline \multicolumn{2}{|c|}{ Customer Retention } & 4 & 0.953 & 0.951 & 0.828 & 0.382 \\
\hline \multicolumn{2}{|c|}{ Relationship Commitment } & 4 & 0.917 & 0.924 & 0.753 & 0.263 \\
\hline \multicolumn{2}{|l|}{ Trust } & 4 & 0.920 & 0.919 & 0.742 & 0.329 \\
\hline \multicolumn{2}{|c|}{ Functional Quality } & 4 & 0.818 & 0.820 & 0.541 & 0.272 \\
\hline \multicolumn{2}{|c|}{ Communication Effectiveness } & 4 & 0.901 & 0.901 & 0.695 & 0.325 \\
\hline \multicolumn{2}{|c|}{ Technical Quality } & 3 & 0.828 & 0.828 & 0.618 & 0.084 \\
\hline
\end{tabular}

\section{Statistical Results}

\section{Descriptive Statistics}

Table 2 elaborates the demographics and the composition of the data used in the study. The composition included categories of gender, age, and occupation of the respondents. The valid sample comprises of $41 \%$ Male and $59 \%$ Female. The age group of the studied sample included $40 \%$ respondents of 18 to 22 years of age, 55\% respondents of 23 to 27 years of age and 5\% respondents are above 27 years of age. Furthermore, $63 \%$ of the respondents are unemployed, $35 \%$ are employed and $2 \%$ are self-employed.

Before carrying out the data analysis assumptions of SEM were checked; sample size, normality within the variables, outliers, scales of the variables and multicollinearity (Hair et.al, 2006). According to (Hair et.al, 2006), the adequate sample size for a study is 50 to 400 observations. In the present study, the given study the sample size is 321 which is adequate as per the requirement. For analysis of normality, the acceptable range of skewness and kurtosis is \pm 1 , which indicates a symmetric distribution. Table 2 indicates that the data is normal as the 
values lie between desired ranges. As mentioned earlier, both univariate and multivariate outliers were removed from the dataset so as to fulfill the assumptions of SEM.

Table 2: Descriptive Statistics

\begin{tabular}{llccc}
\hline \multicolumn{5}{c}{ Gender } \\
\hline Valid & Male & Frequency & Percent & Cumulative Percent \\
& Female & 133 & 41.4 & 41.4 \\
& Total & 188 & 58.6 & 100.0 \\
\hline \multicolumn{5}{c}{ Age } \\
\hline Valid & $18-22$ & Frequency & Percent & Cumulative Percent \\
& 23-27 & 129 & 40.2 & 40.2 \\
& 27 and above & 177 & 55.1 & 95.3 \\
& Total & 15 & 04.7 & 100.0 \\
\hline \multicolumn{5}{c}{ Occupation } \\
\hline
\end{tabular}

\section{Exploratory Factor Analysis}

For extraction of dimensions, EFA and varimax are performed. 15 factors have been developed. To measure the adequacy of the sample, Kaiser-Meyer-Olkin exhibits the value of 0.835 which is above 0.7, which depicts the sample to be sufficient enough for performing factor analysis (Leech, Barrett, \& Morgan, 2005). Bartlett's test of sphericity (Approx. Chi-Square = $16433.554, \mathrm{df}=1540, \mathrm{p}<.000)$ describes that the correlation matrix is significantly dissimilar from the identity matrix and correlation among variables is not zero (Leech et al., 2005).

Following the criteria for factors extraction explained in the Hair et.al (2006), the methods of latent root, the percentage of variance explained and scree test together leads to the conclusion of retaining twelve factors for the analysis. These fifteen components depict $74.723 \%$ of the total variance explained with Eigenvalues above 1 . The rotated component matrix with factors loadings above 0.55 are considered good (Tabachnick \& Fidell, 2007), the factors loading of all items are above the desired level. The resulting solution shown in Table -3 doesn't show any cross loading among the items indicating no issue of discriminant validity. 
Table 3: Factor Loadings

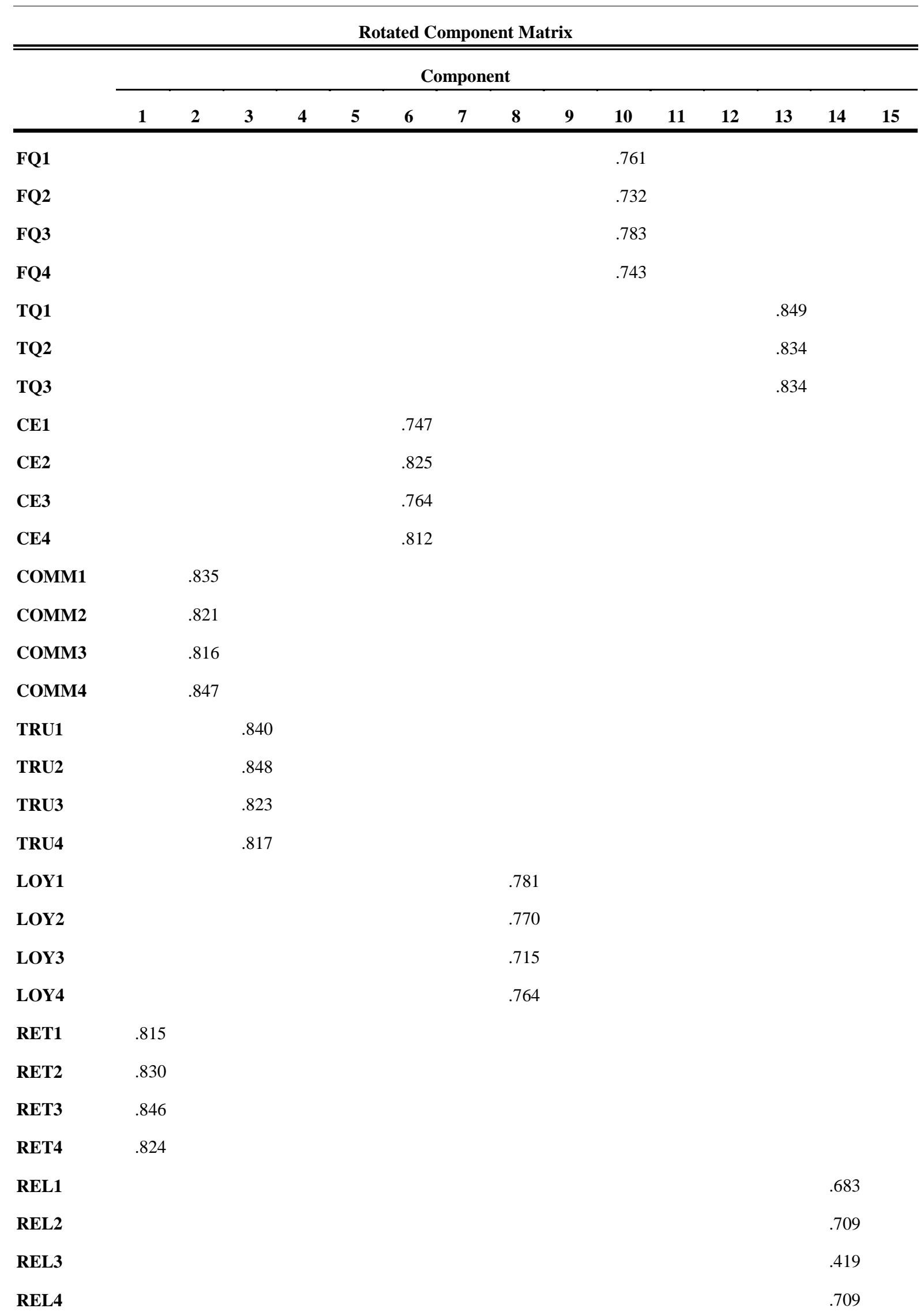


The integration of Loyalty, Satisfaction and Relationship Commitment models to predict Customer Retention in Pakistani Telecom sector

\begin{tabular}{|c|c|c|c|c|c|c|c|c|c|c|c|c|c|c|c|}
\hline \multicolumn{16}{|c|}{ Rotated Component Matrix } \\
\hline & \multicolumn{15}{|c|}{ Component } \\
\hline & 1 & 2 & 3 & 4 & 5 & 6 & 7 & 8 & 9 & 10 & 11 & 12 & 13 & 14 & 15 \\
\hline EMP1 & & & & & & & & & .771 & & & & & & \\
\hline EMP2 & & & & & & & & & .660 & & & & & & \\
\hline EMP3 & & & & & & & & & .787 & & & & & & \\
\hline EMP4 & & & & & & & & & .802 & & & & & & \\
\hline TAN1 & & & & & & & & & & & .893 & & & & \\
\hline TAN2 & & & & & & & & & & & .899 & & & & \\
\hline TAN3 & & & & & & & & & & & .877 & & & & \\
\hline RESP1 & & & & & & & .829 & & & & & & & & \\
\hline RESP3 & & & & & & & .827 & & & & & & & & \\
\hline RESP2 & & & & & & & .815 & & & & & & & & \\
\hline RESP4 & & & & & & & .849 & & & & & & & & \\
\hline
\end{tabular}

$\begin{array}{lr}\text { ASSU1 } & .622\end{array}$

$\begin{array}{lr}\text { ASSU2 } & .787\end{array}$

$\begin{array}{lr}\text { ASSU3 } & .627\end{array}$

SAT1 .889

SAT2 .892

SAT3 .867

SAT4 .838

HAB1 .888

HAB2 .854

HAB3 .865

HAB4 .881

$\begin{array}{ll}\text { VAL1 } & .849\end{array}$

$\begin{array}{lll}\text { VAL2 } & .874\end{array}$

VAL3 $\quad .866$

Extraction Method: Principal Component Analysis.

Rotation Method: Varimax with Kaiser Normalization.

a. Rotation converged in 7 iterations.

Discriminant validity was also checked through component transformation; all the values are below the threshold value 0.70 (Tharenou, Donohue \& Cooper, 2007), Table -4 . 
Table 4: Component Transformation Matrix (Discriminant Validity)

\begin{tabular}{|c|c|c|c|c|c|c|c|c|c|c|c|c|c|c|c|}
\hline \multicolumn{16}{|c|}{ Component Transformation Matrix } \\
\hline Component & 1 & 2 & 3 & 4 & 5 & 6 & 7 & 8 & 9 & 10 & 11 & 12 & 13 & 14 & 15 \\
\hline 1 & .467 & .407 & .387 & .198 & -.010 & .404 & .051 & .367 & .053 & .291 & .053 & .081 & .172 & .024 & .013 \\
\hline 2 & -.056 & -.036 & -.158 & .041 & -.239 & -.009 & .208 & .012 & .656 & -.005 & .156 & .016 & .123 & .462 & .429 \\
\hline 3 & -.018 & .029 & .010 & .004 & .811 & -.143 & .124 & .033 & .102 & -.013 & -.024 & .515 & -.035 & .093 & .134 \\
\hline 4 & -.132 & -.032 & -.253 & .866 & -.119 & -.010 & -.015 & -.011 & -.038 & .105 & -.304 & .187 & -.100 & -.015 & -.047 \\
\hline 5 & -.060 & -.003 & -.108 & -.051 & -.103 & -.015 & .922 & .130 & -.232 & .086 & .088 & .011 & -.135 & -.101 & -.080 \\
\hline 6 & .010 & -.234 & -.078 & .313 & .138 & .182 & -.048 & -.124 & -.106 & -.080 & .841 & -.041 & .154 & -.144 & -.001 \\
\hline 7 & -.470 & .086 & -.290 & -.191 & .048 & .146 & -.135 & .088 & -.153 & .695 & .039 & .027 & .297 & .033 & .056 \\
\hline 8 & .060 & -.490 & -.024 & .065 & .332 & .312 & .157 & .099 & .107 & -.069 & -.351 & -.443 & .409 & .006 & -.081 \\
\hline 9 & -.179 & .511 & .137 & .154 & .059 & -.338 & .150 & -.291 & -.019 & -.194 & -.009 & -.173 & .596 & .007 & -.126 \\
\hline 10 & -.350 & -.032 & 609 & .146 & .142 & .090 & .083 & -.338 & .075 & .267 & .012 & -.303 & -.377 & .078 & .133 \\
\hline 11 & -.201 & -.426 & .495 & -.022 & -.310 & -.061 & .020 & .079 & -.167 & -.071 & -.057 & .498 & .364 & -.009 & .098 \\
\hline 12 & -.174 & -.042 & .125 & .134 & .079 & -.506 & -.102 & .700 & .021 & -.005 & .129 & -.312 & -.058 & -.104 & .131 \\
\hline 13 & .477 & -.287 & .036 & .022 & -.020 & -.523 & .028 & -.236 & .104 & .529 & .050 & -.023 & .079 & .056 & -.234 \\
\hline 14 & .269 & .010 & -.080 & .027 & .011 & -.087 & .015 & -.184 & -.337 & .048 & -.127 & -.122 & .081 & -.247 & .815 \\
\hline 15 & .090 & -.026 & -.007 & .051 & .046 & -.029 & -.043 & .056 & -.544 & -.081 & .041 & -.110 & -.031 & .815 & -.002 \\
\hline
\end{tabular}

Extraction Method: Principal Component Analysis.

Rotation Method: Varimax with Kaiser Normalization.

\section{Confirmatory Factor Analysis}

The study further performed confirmatory factor analysis (CFA) with 57 final loaded items that represent fifteen factors namely, reliability (REL), assurance (ASSU), tangibility (TAN), responsiveness (RESP), empathy (EMP), service satisfaction (SAT), trust (TRU), loyalty (LOY), relationship commitment (COMM), customer retention (RET), functional quality (FQ), technical quality (TQ), communication effectiveness (CE), perceived value (VAL) and habit (HAB). Table 1 presents the number of final items extracted, results of the construct and convergent validity including composite reliability (CR) and average variance explained (AVE). Furthermore, the recommended criteria for CR and AVE state that a scale is considered reliable if it has AVE above 0.5 and CR above 0.7 (Bagozzi \& Yi, 1988); however, in our study $\mathrm{CR}$ is slightly less than 0.7 for the construct Service quality. A CR value between 0.6 to 0.7 may also be acceptable if another indicator (i.e factor loadings > 0.5) of a model's construct validity are good (See Table no. 3) (Hair et al., 2006). The AVE of each construct was compared with the maximum shared variance (MSV) and as all AVE values were greater than the maximum shared variance of the constructs, except for the variable habit (See Table no.1) and it can be attributed to method biasness issue, thus no issue of discriminant validity existed in our study (Voorhees, Brady, Calantone, \& Ramirez, 2016; Waseem, Frooghi \& Khan, 2016) and the model can be further carried for the study purpose.

The CFA model is a projection of association between observed and unobserved variables (Bryne, 2013). Measurement model relies on the assessment of its model fitness. 
According to McDonald and Ho (2002), the most frequently stated model fitness indices are Comparative Fit index (CFI). Various indices are important individually since all represent different aspects of model fitness (Crowley and Fan, 1997). Thus there exists no consensus in literature for any single index of measuring model fitness. Kline (2005) strongly suggested the combination of Chi-Square test, the root mean square error of approximation (RMSEA) and CFI. These indices are preferred over other indices since they are most insensitive to sample size, misleading and parameter estimates. Following Kline (2005) recommendation, Table - 5 presents the goodness of fit indices for our final hypothesized model.

Table 5: Summary of Model Comparisons

\begin{tabular}{|c|c|c|c|c|}
\hline & CMIN / DF & TLI & CFI & RMSEA \\
\hline $\begin{array}{l}\text { Recommended } \\
\text { Value }\end{array}$ & $<5^{\mathrm{a}}$ & $\geq 0.90^{\mathrm{b}}$ & $\geq 0.90^{\circ}$ & $\leq 0.05^{\mathrm{d}}$ \\
\hline Null Model & 11.468 & 0.000 & 0.000 & 0.154 \\
\hline One Factor Model & 6.948 & 0.432 & 0.462 & 0.116 \\
\hline $\begin{array}{l}\text { Hypothesized } \\
\left.\text { Model ( } 1^{\text {st }} \text { order }\right)\end{array}$ & 1.797 & 0.924 & 0.933 & 0.042 \\
\hline $\begin{array}{l}\text { Hypothesized } \\
\left.\text { Model ( } 2^{\text {nd }} \text { order }\right)\end{array}$ & 1.768 & 0.927 & 0.934 & 0.042 \\
\hline SEM Model & 1.924 & 0.911 & 0.917 & 0.046 \\
\hline
\end{tabular}

For measurement of goodness of fit of the measurement model, four common measures have been used; CMIN/DF as proposed by Byrne (2013), TLI as proposed by Hu \& Bentler (1998), CFI as proposed by Bryne (1994) and RMSEA as proposed by Steiger (1990).

As shown in Table-5 the CMIN/DF value of our CFA model (1st order) is calculated as 1.797, TLI value is 0.924 , CFI value is calculated as 0.933 and RMSEA value is measured to be 0.042 which is satisfied cut-off level values described by different authors.

2nd Order CFA model was developed so as to develop a new latent variable service quality dimension which describes the variables named assurance, tangibility, responsiveness, empathy and reliability. The model was measured for its goodness of fit, Table-5, CMIN/DF value is calculated as 1.768 , TLI value is 0.927 , CFI value is 0.934 and RMSEA value is 0.042 .

\section{Structural Equation Modeling}

Table -5 shows the results of Structural Analysis Model. It has been analyzed that the model is a good fit model. The Chi-Square of the model is measured to be 2659.861, CMIN/DF value is calculated as 1.924, TLI value is 0.911 , CFI value is 0.917 and RMSEA value is calculated to be 0.046 . 
Table 6: SEM Hypothesis Testing

\begin{tabular}{|c|c|c|c|c|c|c|c|c|}
\hline \multirow{2}{*}{$\begin{array}{c}\text { Hypothesis } \\
\mathrm{H} 12\end{array}$} & \multicolumn{3}{|c|}{$\begin{array}{c}\text { Hypothesized } \\
\text { Path }\end{array}$} & \multirow{2}{*}{$\begin{array}{c}\begin{array}{c}\text { Path } \\
\text { Coefficient }\end{array} \\
.148\end{array}$} & \multirow{2}{*}{$\begin{array}{c}\text { S.E. } \\
.071\end{array}$} & \multirow{2}{*}{$\begin{array}{c}\text { C.R. } \\
2.098\end{array}$} & \multirow{2}{*}{$\frac{\begin{array}{c}\text { p- } \\
\text { value }\end{array}}{.036}$} & \multirow{2}{*}{$\begin{array}{l}\text { Remarks } \\
\text { Supported }\end{array}$} \\
\hline & TRU & $<--$ & $\overline{F Q}$ & & & & & \\
\hline H11 & TRU & $<--$ & TQ & .079 & .036 & 2.217 & .027 & Supported \\
\hline H13 & TRU & $<---$ & $\mathrm{CE}$ & .368 & .052 & 7.042 & $* * *$ & Supported \\
\hline $\mathrm{H} 1$ & SAT & $<---$ & SQ & .117 & .130 & .898 & .369 & $\begin{array}{c}\text { Not } \\
\text { supported }\end{array}$ \\
\hline H5 & LOY & $<--$ & VAL & .069 & .033 & 2.111 & .035 & Supported \\
\hline H6 & LOY & $<---$ & HAB & -.026 & .035 & -.744 & .457 & $\begin{array}{c}\text { Not } \\
\text { supported }\end{array}$ \\
\hline H9 & COMM & $<---$ & TRU & .533 & .055 & 9.772 & $* * *$ & Supported \\
\hline H8 & LOY & $<---$ & TRU & .372 & .044 & 8.388 & $* * *$ & Supported \\
\hline $\mathrm{H} 3$ & LOY & $<---$ & SAT & .109 & .040 & 2.704 & .007 & Supported \\
\hline H7 & RET & $<--$ & COMM & .203 & .045 & 4.510 & $* * *$ & Supported \\
\hline $\mathrm{H} 4$ & RET & $<--$ & LOY & .538 & .074 & 7.247 & $* * *$ & Supported \\
\hline $\mathrm{H} 2$ & RET & $<---$ & SAT & .102 & .049 & 2.110 & .035 & Supported \\
\hline $\mathrm{H} 10$ & RET & $<--$ & TRU & .383 & .059 & 6.490 & $* * *$ & Supported \\
\hline
\end{tabular}

The result indicates that service quality has an insignificant impact on service satisfaction $(\beta=$ $0.117, \mathrm{p}>0.05)$, service satisfaction has a positive and significant impact on customer retention $(\beta=0.102, \mathrm{p}<0.05)$, customer satisfaction has a positive and significant impact on customer loyalty $(\beta=0.109 * *)$. All four including customer loyalty, $(\beta=0.538 * * *)$, relationship commitment $\left(\beta=0.203^{* * *}\right)$, service satisfaction $(\beta=0.102, \mathrm{p}<0.05)$ and trust $\left(\beta=0.383^{* * *}\right)$ have positive and significant relationship with customer retention in our study. On the other hand, only the variable habit was found having insignificant impact on loyalty $(\mathrm{p}>0.05)$ while perceived value $(\beta=0.069, \mathrm{p}<0.05)$, customer satisfaction $(\beta=0.109, \mathrm{p}<0.05)$ and trust $(\beta$ $=0.372 * * *)$ all having significant impact on customer loyalty within Pakistani context. Also the three sub factors technical quality, functional quality and communication effectiveness do significantly influence the factor trust; with all p-values less than 0.05 and in turn Trust leads to significant positive influence on relationship commitment $(\beta=0.533 * * *)$.

\section{Discussion, Implication, and Recommendation}

The research conducted develops an integrative model regarding the factors that increase customer retention in telecom sector of Pakistan. The model of the study is developed by combining SERVQUAL Model Parasuraman et al. (1988), relationship commitment model Sharma \& Patterson (1999) and customer loyalty model Lin \& Wang (2006); the implication of these models is studied on customer retention. The research finding advocates well integration of the factors and is also found to be empirically significant. The statistical analysis signifies a significant contribution of relationship commitment (COMM), loyalty (LOY) and service satisfaction of (SAT) on customer retention (RET).

Through prominence of incorporation of modern theoretical models, the present study sheds light in the available literature of customer retention and can benefit Pakistan telecom sector to channelize their focus on those aspects that can expand telecom sector in Pakistan. In addition, the study will facilitate marketers to develop marketing strategies for increased acceptance of Telecom Sector. The present findings further indicate a need of framing more 
rational policies that make the implication of policies easy to adopt in organizations. It suggested that management of Pakistan's telecom sector should pay attention to customer commitment by investing more into customer relationship management that can augment customers' dependency and inhibit switching. There is also the need to focus on switching barrier factors such as transaction cost and convenience to ensure retention of telecom customers.

The survey findings established in the present study are based on cross-sectional data gathered from telecom companies located in Karachi. Thus, there exists a need to corroborate the results of the findings on other geographical regions of Pakistan. Furthermore, the study helps in opening avenues for further research on other industries too, along with establishing enhanced customer satisfaction strategies. Also, while this study found that service quality had a weak but positive relationship with customer satisfaction; future research may also attempt to explore some other constructs such as availability of alternatives and convenience issues that consumers in telecom sector would value most.

\section{Reference}

Adamson, I., Chan, K. M., \& Handford, D. (2003). Relationship marketing: customer commitment and trust as a strategy for the smaller Hong Kong corporate banking sector. International journal of bank marketing, 21(6/7), 347-358

Afshan, S., \& Sharif, A. (2016). Acceptance of mobile banking framework in Pakistan. Telematics and Informatics, 33(2), 370-387.

Ahmad, J., Hussain, M., \& Rajput, A. (2015). Customer Loyalty Framework of Telecommunication Service Market. International Journal of Managing Value and Supply Chains, 6(1), 69-76.

Ali, J. F., Ali, I., Rehman, K., Yilmaz, A. K., Safwan, N., \&Afzal, H. (2010). Determinants of consumer retention in cellular industry of Pakistan. African Journal of Business Management, 4(12), 2402-2408.

Alrubaiee, L., \& Al-Nazer, N. (2010). Investigate the impact of relationship marketing orientation on customer loyalty: The customer's perspective. International Journal of Marketing Studies, 2(1), 155-174.

Anderson, E., \& Weitz, B. (1992). The use of pledges to build and sustain commitment in distribution channels. Journal of marketing research, 29(1) 18-34.

Andreassen, T. W. (1999). What drives customer loyalty with complaint resolution?.Journal of Service Research, 1(4), 324-332.

Arslan, M., Iftikhar, M., \& Zaman, R. (2015). Effect of Service Quality Dimensions on Customer Satisfaction: A Comparative Analysis of Pakistan Telecom Sector. British Journal of Marketing Studies, 3(6), 43-62.

Bagozzi, R. P., \& Yi, Y. (1988). On the evaluation of structural equation models. Journal of the Academy of Marketing Science, 16 (1), 74-94

Bolton, R. N., \& Drew, J. H. (1991). A longitudinal analysis of the impact of service changes on customer attitudes. The Journal of Marketing, 55(1), 1-9.

Boohene, R., Agyapong, G. K., \& Gonu, E. (2013). Factors Influencing the Retention of Customers of Ghana Commercial Bank within the Agona Swedru Municipality, 5 (4). International Journal of Marketing Studies, 5(4), 82-95.

Buttle, F. (1996). SERVQUAL: review, critique, research agenda. European Journal of marketing, 30(1), 8-32.

Byrne, B. M. (1994). Structural equation modeling with EQS and EQS/Windows. Thousand Oaks, CA: Sage Publications.

Byrne, B. M. (2013). Structural equation modeling with AMOS: Basic concepts, applications, and programming. Routledge. 
Cardozo, R. N. (1965). An experimental study of customer effort, expectation, and satisfaction. Journal of Marketing Research, 2(3), 244-249.

Caruana, A. (2002). Service loyalty: The effects of service quality and the mediating role of customer satisfaction. European journal of marketing, 36(7/8), 811-828.

Casaló, L. V., Flavián, C., \&Guinalíu, M. (2008). The role of satisfaction and website usability in developing customer loyalty and positive word-of-mouth in the e-banking services. International Journal of Bank Marketing, 26(6), 399-417.

Chen, S. C. (2011). Understanding the effects of technology readness, satisfaction, and electronic word of mouth on loyalty in 3C products. Australian Journal of Business and Management Research, 1(3), 1-9.

Choon Hua, G., Sher, W., \& Sui Pheng, L. (2005). Factors affecting effective communication between building clients and maintenance contractors. Corporate Communications: $A n$ International Journal, 10(3), 240-251.

Chung, C. M., \& Darke, P. R. (2006). The consumer as advocate: Self-relevance, culture, and word-of-mouth. Marketing Letters, 17(4), 269-279.

Clark, G.J. (1992). Quality in finance. Management Services, 36(9), 6-24.

Crowley, S. L., \& Fan, X. (1997). Structural equation modeling: Basic concepts and applications in personality assessment research. Journal of personality assessment, 68(3), 508-531.

Edvardsson, B., Johnson, M. D., Gustafsson, A., \&Strandvik, T. (2000). The effects of satisfaction and loyalty on profits and growth: products versus services. Total quality management, 11(7), 917-927.

Eggert, A., \& Ulaga, W. (2002). Customer perceived value: a substitute for satisfaction in business markets?. Journal of Business \& industrial marketing, 17(2/3), 107-118.

Flavián, C., Guinalíu, M., \& Gurrea, R. (2006). The role played by perceived usability, satisfaction and consumer trust on website loyalty. Information \& Management, 43(1), $1-14$.

Fornell, C. (1992). A national customer satisfaction barometer: the Swedish experience. The Journal of Marketing, 56(1), 6-21.

Fornell, C., Johnson, M. D., Anderson, E. W., Cha, J., \& Bryant, B. E. (1996). The American customer satisfaction index: nature, purpose, and findings. The Journal of Marketing, 60(4), 7-18.

Gawyar, E. T. H., Ehsani, M., \& Kozehchian, H. (2014). Measuring service quality of state clubs in Lorestan province using SERVQUAL model.International Journal of Sport Studies, 4(2), 233-237.

Gronroos, C. (1988). Service quality: The six criteria of good perceived service. Review of business, 9(3), 10-13.

Gustafsson, A., Johnson, M. D., \&Roos, I. (2005). The effects of customer satisfaction, relationship commitment dimensions, and triggers on customer retention.Journal of marketing, 69(4), 210-218.

Haemoon, O. (2000). Diners' perceptions of quality, value, and satisfaction: A practical viewpoint. The Cornell Hotel and Restaurant Administration Quarterly, 41(3), 585-66.

Haghighi, M., Dorosti, A., Rahnama, A., \& Hoseinpour, A. (2012). Evaluation of factors affecting customer loyalty in the restaurant industry. African Journal of Business Management, 6(14), 5039-5046.

Hair Jr, J. F., Black, W. C., Babin, B. J., Anderson, R. E., \& Tatham, R. (2006). Multivariate data analysis. Prentice Hall, New Jersey.

Hallowell, R. (1996). The relationships of customer satisfaction, customer loyalty, and profitability: an empirical study. International journal of service industry management, $7(4), 27-42$. 
Hansen, H., Sandvik, K., \&Selnes, F. (2003). Direct and indirect effects of commitment to a service employee on the intention to stay.Journal of Service Research, 5(4), 356-368

Headley, D. E., \& Choi, B. (1992). Achieving service quality through gap analysis and a basic statistical approach.Journal of Services Marketing, 6(1), 5-14.

Hennig-Thurau, T. (2004). Customer orientation of service employees: Its impact on customer satisfaction, commitment, and retention. International Journal of Service Industry Management, 15(5), 460-478.

Hu, L. T., \& Bentler, P. M. (1998). Fit indices in covariance structure modeling: Sensitivity to underparameterized model misspecification. Psychological methods, 3(4), 424-453.

Johnson, M. D., Gustafsson, A., Andreassen, T. W., Lervik, L., \& Cha, J. (2001). The evolution and future of national customer satisfaction index models. Journal of economic Psychology, 22(2), 217-245.

Johnson, M. D., Herrmann, A., \& Huber, F. (2006). The evolution of loyalty intentions.Journal of Marketing, 70(2), 122-132.

Kärnä, S. (2014). Analysing customer satisfaction and quality in construction-the case of public and private customers. Nordic journal of surveying and real estate research, 2, 67-80.

Keating, B., Rugimbana, R., \& Quazi, A. (2003). Differentiating between service quality and relationship quality in cyberspace.Managing Service Quality: An International Journal, 13(3), 217-232.

Kline, R.B. (2005). Principles and practices of structural equation modeling. New York: Guilford.

Kuo, N. T., Chang, K. C., Cheng, Y. S., \& Lai, C. H. (2013). How service quality affects customer loyalty in the travel agency: The effects of customer satisfaction, service recovery, and perceived value. Asia Pacific Journal of Tourism Research, 18(7), 803822.

Lau, G. T., \& Lee, S. H. (1999). Consumers' trust in a brand and the link to brand loyalty.Journal of Market-Focused Management, 4(4), 341-370.

Leech, N. L., Barrett, K. C., \& Morgan, G. A. (2005). SPSS for intermediate statistics: Use and interpretation. Psychology Press.

Lin, H. H., \& Wang, Y. S. (2006). An examination of the determinants of customer loyalty in mobile commerce contexts. Information \& management, 43(3), 271-282.

Luarn, P., \& Lin, H. H. (2005). Toward an understanding of the behavioral intention to use mobile banking. Computers in human behavior, $21(6), 873-891$.

McDonald, R. P., \& Ho, M. H. R. (2002). Principles and practice in reporting structural equation analyses. Psychological methods, 7(1), 64-82.

McDougall, G. H., \& Levesque, T. (2000). Customer satisfaction with services: putting perceived value into the equation. Journal of services marketing, 14(5), 392-410.

Morgan, R. M., \& Hunt, S. D. (1994). The commitment-trust theory of relationship marketing. The Journal of marketing, 58(3) 20-38.

Oliveira, T., Faria, M., Thomas, M. A., \& Popovič, A. (2014). Extending the understanding of mobile banking adoption: When UTAUT meets TTF and ITM. International Journal of Information Management, 34(5), 689-703.

Oliver, R. L. (1999). Whence consumer loyalty? The Journal of Marketing, 63, 33-44.

Olsen, L. L., \& Johnson, M. D. (2003). Service equity, satisfaction, and loyalty: from transaction-specific to cumulative evaluations. Journal of Service Research, 5(3), 184195.

Orbell, S., \& Verplanken, B. (2015). The strength of habit. Health psychology review, 9(3), 311-317. 
Pakdil, F., Kurtulmuşoğlu, F. B., \&Yolu, E. (2014).Improving service quality in highway passenger transportation: a case study using quality function deployment. EJTIR, 14(4), 375-393.

Pakistan Economic Survey (2014-2015). Retrieved from http://www.finance.gov.pk/survey/chapters_15/Highlights.pdf

Parasuraman, A. (2000). Technology Readiness Index (TRI) a multiple-item scale to measure readiness to embrace new technologies. Journal of service research, 2(4), 307-320.

Parasuraman, A., Berry, L. L., \&Zeithaml, V. A. (1991). Refinement and reassessment of the SERVQUAL scale. Journal of retailing, 67(4), 420-450.

Parasuraman, A., Zeithaml, V. A., \& Berry, L. L. (1985). A conceptual model of service quality and its implications for future research. The Journal of Marketing, 49(4), 41-50.

Parasuraman, A., Zeithaml, V., \& Berry, L. (1988). SERVQUAL: a multiple-item scale for measuring consumer perceptions of service quality. Journal of Retailing, 64(1), 12-37.

Pasebani, F., Mohammadi, S., \& Yektatyar, M. (2012). The relationship between organizational learning culture and job satisfaction and internal service quality in sport organizations in Iran. Archives of Applied Science Research, 4(4), 1901-1905.

Sekaran, U. (2006). Research methods for business: A skill building approach. John Wiley \& Sons.

Sharma, N., \& Patterson, P. G. (1999). The impact of communication effectiveness and service quality on relationship commitment in consumer, professional services. Journal of services marketing, 13(2), 151-170.

Sharma, N., \& Patterson, P. G. (2000). Switching costs, alternative attractiveness and experience as moderators of relationship commitment in professional, consumer services. International journal of service industry management, 11(5), 470-490.

Sharma, N., \& Patterson, P. G. (2000). Switching costs, alternative attractiveness and experience as moderators of relationship commitment in professional, consumer services. International journal of service industry management, 11(5), 470-490.

State Bank of Pakistan, Quarterly Report External Sector (2016). Retrieved from http://www.sbp.org.pk/reports/quarterly/fy17/Second/Chap-5.pdf

Steiger, J. H. (1990). Structural model evaluation and modification: An interval estimation approach. Multivariate Behavioral Research, 25, 173-180.

Sweeney, J., Soutar, G., \&Mazzarol, T. (2014). Factors enhancing word-of-mouth influence: positive and negative service-related messages. European Journal of Marketing, 48(1/2), 336-359.

Szyperski, N., \& Loebbecke, C. (1999). Telekommunikationsmanagement (TKM) alsbetriebswirtschaftliche Spezialdisziplin. Die Betriebswirtschaft, 59, 481- 495.

Tabachnick, B. G., \& Fidell, L. S. (2007) Using multivariate statistics, Harper and Row.

Tharenou, P., Donohue, R., \& Cooper, B. (2007). Management research methods. New York, NY: Cambridge University Press.

Van Riel, A. C., Liljander, V., \&Jurriens, P. (2001). Exploring consumer evaluations of eservices: a portal site.International Journal of Service Industry Management, 12(4), 359-377.

Verhoef, P. C. (2003). Understanding the effect of customer relationship management efforts on customer retention and customer share development. Journal of marketing, 67(4), 30-45.

Voorhees, C. M., Brady, M. K., Calantone, R., \& Ramirez, E. (2016). Discriminant validity testing in marketing: an analysis, causes for concern, and proposed remedies. Journal of the Academy of Marketing Science, 44(1), 119-134. 
Wang, Y., Lo, H. P., \& Yang, Y. (2004). An integrated framework for service quality, customer value, satisfaction: Evidence from China's telecommunication industry. Information systems frontiers, 6(4), 325-340.

Waseem, S.N., Frooghi, R., \& Khan, B.S. (2016). Empirical Assessment of the Constructs: Workplace Engagement, Job Burnout and Turnover Intention. Journal of Education \& Social Sciences, 4(2), 112-131.

Yavas, U., \& Benkenstein, M. (2007). Service quality assessment: a comparison of Turkish and German bank customers. Cross Cultural Management: An International Journal, 14(2), 161-168.

Yoon, C. (2010). Antecedents of customer satisfaction with online banking in China: The effects of experience. Computers in Human Behavior, 26(6), 1296-1304.

Zang, Z., Gao, S., \& Yang, Y. (2014, June). An Examination of the Determinants of Customer Loyalty in Online Group-buying Context in China. In WHICEB (p. 57).

Zeithaml, V. A. (2000). Service quality, profitability, and the economic worth of customers: what we know and what we need to learn. Journal of the academy of marketing science, 28(1), 67-85. 


\section{Appendix}

Tangibles (TAN): Wang, Lo \& Yang (2004).

TA1 Telecommunication industry has up-to-date equipments.

TA2 Physical facilities are virtually appealing.

TA3 Employees are well dressed and appear neat.

TA4 Physical environment of the Telecommunication companies is clean.

\section{Reliability (REL): Wang, Lo \& Yang (2004).}

REL1 When service providers promise to do something by a certain time, they do it.

REL2The service provider always performs the service right the first time

REL3 They provide their services at the time they promise to do so.

REL4 When customers have a problem, the service provider shows a sincere interest in solving it

Responsiveness (RESP): Wang, Lo \& Yang (2004).

RESP1 The employees tell me exactly when services will be performed

RESP2 Employees give prompt services to customers.

RESP3 Employees are always willing to help customers.

RESP4 Employees are never too busy to respond to customers requests.

\section{Assurance (ASSU): Wang, Lo \& Yang (2004).}

ASSU1 The behaviour of employees instill confidence in customers

ASSU2 Customers feel safe in their transactions with the employees

ASSU3 The employees are consistently courteous with customers

ASSU4 The employees have knowledge to answer customers' questions

Empathy (EMP): Wang, Lo \& Yang (2004).

EMP1 Telecommunication industry give customers individual attention.

EMP2 Employees of telecommunication companies give customers personal attention.

EMP3Telecommunication industry have their customers' interest at heart.

EMP4The employees understand customers' specific needs

Satisfaction SAT: Wang, Lo \& Yang (2004).

SAT1 I am satisfied with products and services provided by my company

SAT2 I feel very pleased with delivered services

SAT3 I feel absolutely delighted.

SAT4 The overall service quality provided by my company is excellent

Value (VAL) :Wang, Lo \& Yang (2004).

VAL1 Overall, the chosen offerings are value for money.

VAL2 The chosen offerings are worth what is given up such as time, energy and effort.

VAL3 Comparing with major competitors, the transaction with the provider is a good choice

\section{Customer loyalty (LOY): Lin and Wang (2006)}

LOY1: My preference for my service provider would not willingly change.

LOY2: It would be difficult to change my beliefs about my service provider

LOY3: I intend to keep using my telecom service.

LOY4: Even if close friends recommended another telecom service provider, my preference for my own would not change. 


\section{Relationship Commitment (COM): Verhoef (2003)}

Comm1: I am a loyal customer of my service provider.

Comm2: Because I feel a strong attachment to my service provider, I remain a customer of my service provider.

Comm3: Because I feel a strong sense of belonging with my service provider, I want to remain a customer of my service provider.

Comm4: I have the intention to maintain longterm relationship with my service provider.

\section{Trust (TRU): Alrubaiee\& Al-Nazer (2010)}

TRU1 My Service provider has high integrity

TRU2 My Service Provider is consistent in providing quality service

TRU3 My Service provider is reliable in providing unique services

TRU4 My service provider is trustworthy

\section{Customer Retention (CR)}

CR1 In future I will perform my telecommunication services from my service provider. Hennig (2004)

CR2 I intend to continue the telecom relationshipwith my service provider.Eggert and Ulaga (2002)

CR3 Next time I will buy again from my current service provider.Eggert and Ulaga (2002)

CR4 I am a loyal customer of my service provider. Hennig (2004) 